\title{
Does Fresh Air make the Difference; a Comparative Study in Vitamin D Status among College Adolescent Females from Giza and Red Sea Governorates
}

\author{
Dina IS ${ }^{1}$, El-Sayed $\mathrm{MM}^{2}$, and Salem $\mathrm{AH}^{3}$ \\ ${ }^{I}$ Department of Clinical Nutrition; National Nutrition Institute, Cairo, Egypt \\ ${ }^{2}$ Department of Nutrition and Food Science, Menofia University. \\ ${ }^{3}$ M Sc student Department of Nutrition and Food Science, Menofia University.
}

\section{Abstract}

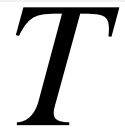

he level of air pollution is negatively associated with the amount of solar ultra-violet ray $B(U V B)$ that reaches earth surface. So, more pollutant areas lead to less UVB passage and consequently, $25(\mathrm{OH})$ vitamin D cutaneous syntheses reduces. The research was carried out to study the effect of some biological, behavioral, and environmental factors on vitamin D level among college adolescent females from Red Sea and Giza governorates. A convenient sample consisted of 151 first grade university female youth was selected. Written consent was an initial basic step. Vitamin D intake was assessed and serum calcium, phosphorus, alkaline phosphatase, 25-hydroxyvitamin D [25(OH) D], and parathyroid hormone (PTH), were measured. Food intake was compared to the recommended dietary allowances. Results revealed that majority of respondents (92.0\%) were veiled and exposed to sun at noon time and $61.0 \%$ mentioned that sun- exposure took more than an hour. Waist circumference (WC) and waist to height ratio (WC to Ht) in Giza sample and increased fish consumption per week in Red Sea sample showed a positive effect on vitamin D status. Spring season had a negative influential effect on Giza participants. This study concluded that lack of sun exposure as the main cause of vitamin D deficiency in college female, there is also limited awareness of the association between sun exposure and vitamin D synthesis. Fresh air and good food practices could aid in solving health problems with such an influence as hypovitaminosis D. This study emphasized the need for further vitamin $D$ assessment and intervention by supplementation or fortification of a staple food item. There is also an urgent need for public education to improve vitamin $D$ - related practice and to minimize health hazards of improper exposure to UV B rays.

Key words: UVB, Vitamin D food sources, College females

Bulletin of the National Nutrition Institute of the Arab Republic of Egypt. June 2019 (53) 94 
Dina $I S^{1}$, El-Sayed $M M^{2}$, and Salem $\mathrm{AH}^{3}$

\section{INTRODUCTION}

It is evident from many studies that vitamin D intake is often too low to sustain healthy circulating levels of 25hydroxyvitmain $\mathrm{D}$ in countries unless there is mandatory staple food fortification, such as with milk and margarine. Even in countries that do fortify, vitamin $D$ intakes are low in some groups; particularly adolescents, due to their unique dietary patterns, such as low milk consumption, vegetarian diet, limited use of dietary supplements, or loss of traditional high fish intakes (Calvo, et al., 2017).

Also, biological (including skin melanisation) and behavioral factors (including lower levels of dietary vitamin $\mathrm{D}$, sun-screen use and personal UV exposure) may contribute. A cross-sectional study showed that vegetarians and vegans had lower circulating $25(\mathrm{OH}) \mathrm{D}$ than meat and fish eaters (The report of advisory group on nonionizing radiation, 2017).
This research was carried out to investigate the effect of fresh air and fish-eating pattern on vitamin $\mathrm{D}$ status of college females.

\section{SUBJECTS \&METHODS}

Subjects:

Two convenient University samples were selected; 69 from Red Sea governorate (Helwan University hostel' attendants) and 82 from Giza governorate (lectures lab).

\section{Methods:}

- Food intake was recorded using 24 hour recall and food frequency sheets (Hammond and Mahan 2017), analyzed using the computerized form of the food composition table of the National Nutrition Institute (2006) and then compared to the recommended dietary allowances based on FAO/WHO/UNU recommendations (2004).

- Weight, height, and waist were measured, BMI was calculated (Litchford, 2017), 
Dina $I S^{I}$, El-Sayed $M M^{2}$, and Salem $\mathrm{AH}^{3}$

and blood pressure evaluation was done with a standard clinical sphygmomanometer.

\section{Laboratory indicators}

Laboratory indicators were measured using (Stanbio Total Calcium Liquicolor, Procedure No 0150) for calcium (Ca) (Sarkar and Chauhan, 1967), (BioMed -phosphorous (PH123100)) for phosphorus (P) (Vassault, et al., 1989), and (DRG-DEA) Kinetic method for alkaline phosphatase (ALP) (Tiets, 1995). All previous tests were done using spectrometric device (Kenza, France). Serum 25-OH vitamin D was done by DRG ELISA LOT: 80k035 Cat .Nr:EIA5396 (Houghton and Vieth, 2006) and Serum Parathyroid hormone (PTH) was done by immune-enzymatic assay (hPTH-ASIA) Cat NO.:kAP1481 (Martin, et al., 1979). Blood samples were delivered to the National Nutrition Institute (NNI) labs for testing.
Data processing and analysis:

Data were summarized using median (inter-quartile range) or frequency and percentage $(\%)$ for categorical data. Mann-Whitney and Kruskall-Walis tests were used in comparisons. The coefficients of determination were calculated using Spearman's bivariate analysis. A two tailed $p$ value of $<\quad 0.05$ was considered statistically significant. All statistical analyses were performed using statistical software SPSS (IBM SPSS Statistics, SPSS Inc., Chicago, IL) (Sabine and Brian, 2004)

\section{RESULTS \& DISCUSSION}

The distribution of participated college females per season and governorate was nearly the same. One fifth was interviewed in winter $(23.0 \%)$, and $38.0 \%$ and $39.0 \%$ participated in autumn, and spring respectively (table 1).

Table (2) showed that Adolescents aged 17 to 18 years formed $38.0 \%$ of the total examined and the age from 19 to 
Dina $I S^{I}$, El-Sayed $M M^{2}$, and Salem $\mathrm{AH}^{3}$

21 formed the remaining $62.0 \%$. Majority of adolescent females had a faint brown skin (79.0\%) and $94.0 \%$ wore the Islamic women costume. Malnutrition problem reflected by percentage under weighed was slightly higher than the accepted percentage $(7.0 \%$ compared to $2.5 \%$ expected from population normal distribution curve) (Sabine and Brian, 2004). Percentage of obese was even higher $(10.0 \%)$ with no statistical significant difference between their areas of residence.

Clinical evaluation did not show any comparative differences between participants based on anthropometric or blood pressure assessment (table $3)$.

The quartile distribution of vitamin $\mathrm{D}$ and related indicators are shown in Table (4). As an average speaking, $75 \%$ of participants in spring and autumn seasons had their serum level of vitamin $D$ just at or below $30.0 \mathrm{ng} / \mathrm{ml}$ (values mentioned at $75^{\text {th }}$ or $3^{\text {rd }}$ quartile); mainly in the insufficient range and those having their serum level in the normal range constituted the remaining $25 \%$. Results in winter was significantly different and $75 \%$ of values were more to the deficient range $(=<20 \mathrm{ng} / \mathrm{ml})$. Calcium values were just close to the lower normal limit value (9.2) in $50 \%$ of participants regardless of season. In contrast to calcium, phosphorus values were at the upper normal limit value (4.5) in $50 \%$ of samples and other half exceeded even the normal limit. Calcium phosphorus product had the least values in spring and the highest in autumn. Serum alkaline phosphatase levels were in the normal range with no special trend. PTH values were in the

normal range in $75 \%$ of sample regardless of season and the remaining $25 \%$ could have values in the high range.

Table 5 showed results based on Cut-offs of VD, PTH, Calcium, and phosphorus simultaneously (Metabolic 
Dina $I S^{I}$, El-Sayed $M M^{2}$, and Salem $\mathrm{AH}^{3}$

State); the overall distribution showed that $76(50.0 \%)$ of college females were categorized in the VD normal group, one fifth of the sample had only low calcium level (hypocalcemic group), another one fifth had VDD, and only $7.0 \%$ were in the insufficient group.

Taking season into consideration, 7 out of 34 $(21.0 \%)$ of participants in winter were considered VD deficient and 18 out of 34 females (53.0\%) had normal VD levels. As for the autumn sample, 8 out of 58 females (14.0\%) were deficient and 39 out of 58 $(67.0 \%)$ had normal VD values. Unexpectedly, the spring sample showed more percentage in the deficient group (18 out of 59; $31.0 \%$ ) and less percentage in the sufficient group (32.0) with a total significant statistical difference of (0.014).

Distribution of college females per governorate and season, showed that nearly half the participants were in the VD normal group (40 out of 82; $49.0 \%$ ) (Asymp. Sig. =.007) in Giza and $52.0 \%$ in Red sea governorate (36 out of 69) with no significant difference.

Based on WHO recommendations (2006), analysis of previous 24 hours before interview reflected the marked shortage in daily energy intake among respondents as reflected by the median value for energy consumption regardless of area of descent. Three quarters of females' student were receiving below the recommendation of $2200 \mathrm{kcal}$ daily. In contrast, protein intake was nearly $143.0 \%$ of recommendation on average in red sea sample and $133.0 \%$ in Giza sample. Protein energy ratio in red sea sample was 15.5 $\%$ and $13.8 \%$ in Giza sample. Energy from carbohydrates constituted $54.0 \%$ of total energy which was more to the low normal border (not seen in the table) and the average fiber consumption per day was much less the recommendation of 26 gm. Fat intake was the source of 
Dina $I S^{I}$, El-Sayed $M M^{2}$, and Salem $\mathrm{AH}^{3}$

$29.0 \%$ of energy (30.0- $35.5 \%$ is the normal range for that age group(table 6).

Consumption of calcium rich products with every meal will provide the requirements for calcium and many other nutrients essential for bone health. In contrast to accepted average intake of phosphorus, average calcium in diet was significantly less than daily recommendation of 1200 mg daily (FAO/WHO/UNU, 2004).

As for micro-minerals, the average dietary intakes of iron was inadequate if compared to $\mathrm{WHO} / \mathrm{FAO}$

(2004)

recommendations of $29-31 \mathrm{mg}$ and $25.0 \%$ of respondents had zinc intake below the recommendation of $8 \mathrm{mg}$ per day provided that diet composition was of moderate bioavailability for both of them.

Table (7): showed that autumn season had a very significant positive effect on vitamin $\mathrm{D}$ status in college females from Giza governorate that was not seen in participants from Red sea governorate. Meanwhile spring season had a highly significant negative effect on vitamin $\mathrm{D}$ status in participants from Giza governorate and this effect was weakly reported in those from red sea governorate. However, low vitamin D status in spring season can be explained by the fact that females do not like to be tanned by intense sun rays in spring compared to autumn and the weak effect of seasons in Red sea governorate means that vitamin $\mathrm{D}$ status is more or less the same all through the year. Fluctuation of vitamin $\mathrm{D}$ values according to season with lower values during winter and higher values during summer was reported by Quadri and his co-workers (2016).

The same table showed that participated females had nearly same biological (skin pigmentation) criteria and had same sun exposure behaviors. So, the difference in vitamin D status between the two governorates could be mainly referred to the difference in the seasonal 
Dina $I S^{I}$, El-Sayed $M M^{2}$, and Salem $\mathrm{AH}^{3}$

influence particularly in Giza governorate. Vitamin D status was more to the sufficient (normal) status in autumn season compared to spring season in Giza governorate while it was nearly the same in these two seasons in Red sea governorate. Variation in vitamin D synthesis in the skin could be an explanation for this fluctuation from season to other. As air pollution is one of the main elements that influences the percentage of the ground level ultra-violet ray B (UVB). So, more pollutant areas lead to less UVB passage and consequently, $25(\mathrm{OH})$ vitamin $\mathrm{D}$ cutaneous syntheses reduces (The report of advisory group on non-ionizing radiation, 2017).

$\begin{array}{ccc}\text { Social } & \text { level of } \\ \text { participants as reflected by }\end{array}$ number of household members or crowdedness index had a positive effect on vitamin D status in red sea participants. The better the social class is the more is the availability of varied food items.

Unexpectedly, and only in participants from red sea, the usage of sun screen was associated more with sufficient vitamin D status and sunexposure at mid-day showed an opposite association. Many determinants can influence the synthesis of vitamin D in the skin as time and length of sunexposure and being indoor (Hossein panah, et al., 2010). In Giza participants, both of waist circumference and waist to height ratio correlated positively with vitamin D status. This was in contrast with previous studies that considered obesity among risk factors for vitamin D deficiency (Sathya, et al., 2017)

Table (8) showed some associations between adequacy of some minerals and the frequency of consumption of certain food items and vitamin D status. More protein, zinc and iron intakes in daily diet were associated with sufficient vitamin $D$ status in Giza participants. In contrast, increased $\mathrm{Na}$ or $\mathrm{P}$ in diet was more likely to be associated with deficient or insufficient vitamin D level or low calcium level in 
Dina $I S^{I}$, El-Sayed $M M^{2}$, and Salem $\mathrm{AH}^{3}$

Red sea participants. Increased cross vegetables consumption in Giza and fish consumption in red sea governorates had a positive association with vitamin D status. Increased number of meals per day was associated with sufficient vitamin D status and increased trans-fat in diet was associated more with insufficient level of the vitamin. Increased consumption of natural cheese showed a negative association with vitamin $\mathrm{D}$ status and this could be explained by its' high sodium content which increases calcium excretion by renal tubules in exchange with sodium (FAO/WHO/UNU, 2004). Although insignificant, increased milk consumption tended to associate with sufficient vitamin D status in Giza sample.

Foods that make the highest contribution to dietary intakes of vitamin D vary from country to country according to habitual dietary patterns. In some, the predominant food sources are fish and fats or liquid milk and dairy products. Oily fish followed by meat and meat products and cereal and cereal products contribute the highest percentage to average daily vitamin D intakes in adults in Europe.

However, even in those foods considered the richest sources of vitamin $D$, the levels are highly variable. For example, the content of vitamin $\mathrm{D}$ in fish can vary significantly both between and within species and according to whether they are wild or farmed; the vitamin D content of farmed salmon has been shown to be only approximately $25 \%$ that of wild salmon (O'Mahony, et al., 2011). However, results of this study showed that these healthy food items were consumed less than 3 times per week.

\section{CONCLUSION}

This study concluded that lack of sun exposure was the main cause of vitamin D deficiency in college female, there is also limited awareness of the association between sun exposure and vitamin $\mathrm{D}$ 
Dina $I S^{I}$, El-Sayed $M M^{2}$, and Salem $\mathrm{AH}^{3}$

synthesis. Fresh air and good food practices could aid in solving health problems with such an influence as hypovitaminosis D.

\section{RECOMMENDATIONS:}

This study emphasized the need for further vitamin D assessment and intervention by supplementation or fortification of a staple food item. There is also an urgent need for public education to improve vitamin Drelated practice and to minimize health hazards of improper exposure to UV B rays.

\section{REFERENCES:}

Calvo MS; Whiting SJ and Barton CN. (2005):

Vitamin D Intake: A Global Perspective of Current Status. @ American Society for Nutritional Sciences. Jr. Nutrition 310-16.

\section{El-Gilany A; El-Wehady A} and El-Wasify M (2012): Updating and validation of the socioeconomic status scale for health research in Egypt. EMHJ; Vol. 18 (9): 962-66.

FAO/WHO/UNU (2004):

Food and Agriculture Organization, World Health Organization, United Nations University, Rome, Human vitamin and mineral requirements. Report of a Joint FAO/WHO Human energy requirements Report of a Joint $\quad F A O / W H O / U N U$ Expert Consultation.

\section{Hammond KA and Mahan LK} (2017):

(Intake: Analysis of the Diet) in (Krause's Food and the nutrition care process) by Mahan $\mathbf{L K}$ and Raymond JL eds. $14^{\text {th }}$ edition. Elservier

Hossein panah F; Sima H; Heibatollahi M; Moghbel N; Asefzade S and Azizi F. (2010): The effects of air pollution on vitamin $\mathrm{D}$ status in healthy women: a cross 
Dina $I S^{I}$, El-Sayed $M M^{2}$, and Salem $\mathrm{AH}^{3}$

sectional

study.

BMC Public Health;

10:519.

Houghton LA and Vieth $\mathbf{R}$ (2006):

The case against ergocalciferol (vitamin D2) as a vitamin supplement Am. J. Nutr., :84,694-97.

Litchford MD (2017):

(Clinical: Biochemical, Physical, and Functional Assessment) in (Krause's Food and the nutrition care process) by Mahan $\boldsymbol{L K}$ and Raymond JL eds. $14^{\text {th }}$ edition. Elservier.

O'Mahony L; Stepien M; Michael JG; Anne PN; and Lorraine $B$ (2011):

The Potential Role of Vitamin D Enhanced Foods in Improving Vitamin D Status. Nutrients. Dec; 3(12): 1023-1041.

Martin KJ; Hruska KA; and
Freita GJ (1979):

The Peripheral metabolism of parathyroid hormone New Engl. Med, :30120 $: 1092$.

NNI, (1996):

National

Nutrition

Institute food composition table.

Quadri A; Gojanovic B; Noack P;Fuhrer C; Steuer C;Huber $A$ and Kriemler S (2016):

(Seasonal variation of vitamin D levels in Swiss athletes). Swiss Sports \& Exercise Medicine, 64 (1), 19-25, 2016

Report of a joint WHO/FAO/UNU Expert Consultation (2007):

Protein and amino acid requirements in human nutrition. Technical Report Series, No 935.

Sabine L and Brian SE (2004): A Handbook of Statistical Analyses using SPSS. (C) 2004 by Chapman \& 
Dina IS ${ }^{1}$, El-Sayed $M M^{2}$, and Salem $\mathrm{AH}^{3}$

Hall/CRC Press LLC.

Report/ RCE-30/March.

Sarkar BR and Chauhan UPS (1967):

A new method for determining micro quantities of calcium in biological materials. Analytical biochemistry, 20(1), 155-166.

\section{Sathya G; Raji V Sugumar} and Ramesh R (2017):

Seasonal and gender differences in Vitamin D status among the obese adolescents: A prospective study, International Journal of Home Science; 3(1): 297-300.

The Report of the independent Advisory Group on Nonionising Radiation, 2017:

(Ultraviolet radiation, Vitamin D and Health).
Tiets NW (1995):

Clinical Guide to Laboratory Tests $\quad 3^{\text {rd }}$ edition. W.B. Saunders, Co., Philadelphia, PA.

Vassault A; Young DS; Kaplan LA and et al (1989):

Effects of pre analytical variables on clinical laboratory tests, Ann, Bio ,Clin.,:44,686.

\section{WHO (2006):}

Adolescent Nutrition; A Review of the Situation in Selected South-East Asian Countries. SEA-NUT-163. 
Table (1): Percent Frequency Distribution of Participants per season and Government

\begin{tabular}{|c|c|c|c|c|c|c|}
\hline \multirow{2}{*}{ Season } & \multicolumn{2}{|c|}{$\begin{array}{c}\text { Red sea (69) } \\
\text { (row \%) }\end{array}$} & \multicolumn{2}{c|}{$\begin{array}{c}\text { Giza (82) } \\
\text { (row \%) }\end{array}$} & \multicolumn{2}{c|}{$\begin{array}{c}\text { Total (151) } \\
\text { (column \%) }\end{array}$} \\
\cline { 2 - 7 } & No & $\%$ & No & \% & No & $\%$ \\
\hline Winter & 17 & 50.0 & 17 & 50.0 & 34 & 23.0 \\
\hline Autumn & 23 & 40.0 & 35 & 60.0 & 58 & 38.0 \\
\hline Spring & 29 & 47.0 & 30 & 53.0 & 59 & 39.0 \\
& & \multicolumn{3}{|c|}{$\chi^{2}=1.89$} & \multicolumn{3}{c|}{$p=.39$} \\
\hline
\end{tabular}


Does Fresh Air make the Difference; a Comparative Study in Vitamin D Status among College Adolescent Females from Giza and Red Sea Governorates

Dina IS ${ }^{1}$, El-Sayed $M M^{2}$, and Salem $\mathrm{AH}^{3}$

\section{Table (2): Percent Frequency Distribution of Studied Females by some Criteria per Government}

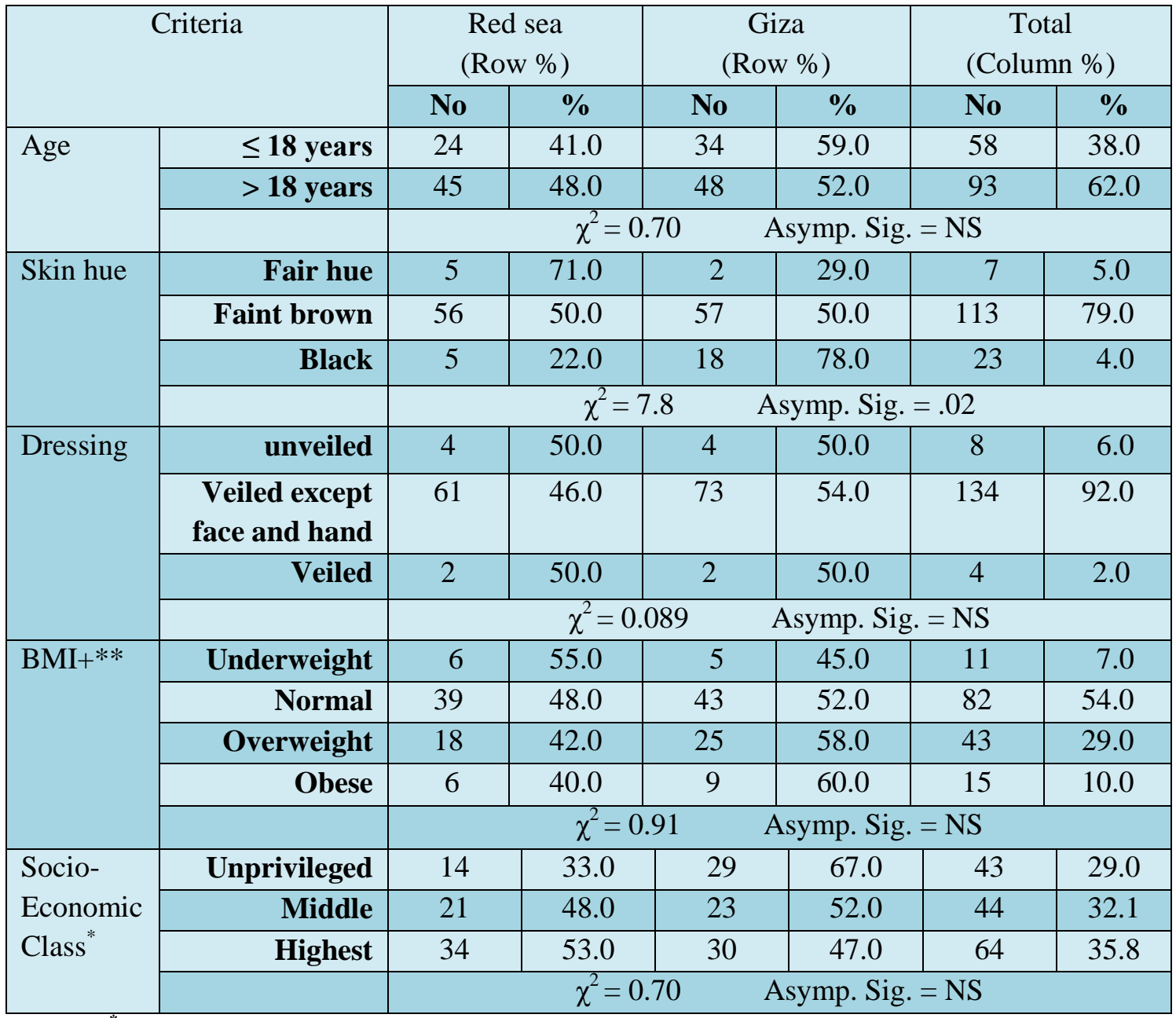

A. El-Gilany, et al., (2012) 
Does Fresh Air make the Difference; a Comparative Study in Vitamin D Status among College Adolescent Females from Giza and Red Sea Governorates

Dina IS ${ }^{I}$, El-Sayed $M M^{2}$, and Salem $A H^{3}$

Table (3): Distribution of Participant Females by their anthropometric data presented as Mean (+/-SD) per

Government

\begin{tabular}{|lc|c|c|c|c|}
\hline \multicolumn{2}{|c|}{ Anthropometry } & Red sea (69) & $\begin{array}{c}\text { Giza } \\
(82)\end{array}$ & \multirow{2}{*}{$\mathrm{T}$} & \\
& & & & \\
\cline { 3 - 5 } & Mean \pm SD & Mean \pm SD & & \\
\hline BMI & $\mathbf{k g} / \mathbf{m}^{2}$ & $23.4 \pm$ & $24.5 \pm$ & 1.6 & NS \\
& & 3.99 & 4.42 & & \\
\hline Height & $\mathbf{c m}$ & $159.9 \pm$ & $161.3 \pm$ & 1.5 & NS \\
& & 5.57 & 5.3 & & \\
\hline Weight & $\mathbf{k g}$ & $60.1 \pm$ & $63.9 \pm 12.99$ & 1.91 & .058 \\
& & 11.16 & & & \\
\hline Waist & $\mathbf{c m}$ & $76.2 \pm$ & $78.1 \pm$ & 1.3 & NS \\
& & 8.72 & 8.75 & & \\
\hline sBPr & $\mathbf{m m H g}$ & $104 \pm$ & $104 \pm$ & -.23 & NS \\
& & 12.5 & 10.4 & & \\
\hline dBPr & $\mathbf{m m H g}$ & $69 \pm$ & $70 \pm$ & .48 & NS \\
& & 9.4 & 8.3 & & \\
\hline
\end{tabular}

$B M I=$ body mass index $/ s B P L=$ systolic blood pressure level/ $d B P L=$ diastolic blood pressure level 
Does Fresh Air make the Difference; a Comparative Study in Vitamin D Status among College Adolescent Females from Giza and Red Sea Governorates

Dina IS ${ }^{I}$, El-Sayed $M M^{2}$, and Salem $A H^{3}$

Table (4): Descriptive of Vitamin D-related Laboratory Indicators presented as Median (IQR*) (Min-Max) per Season:

\begin{tabular}{|c|c|c|c|c|}
\hline \multicolumn{2}{|c|}{$\begin{array}{l}\text { Vitamin D related } \\
\text { Indicators }\end{array}$} & $\begin{array}{l}\text { Winter } \\
(\mathrm{No}=19)\end{array}$ & $\begin{array}{l}\text { Autumn } \\
(\mathrm{No}=69)\end{array}$ & $\begin{array}{l}\text { Spring } \\
(\mathrm{No}=18)\end{array}$ \\
\hline \multirow[t]{2}{*}{$\begin{array}{l}\text { PTH pg/ml } \\
\mathrm{N}=\mathbf{1 6 - 4 6}\end{array}$} & $\begin{array}{l}\text { Median } \\
\text { (IQR) }\end{array}$ & $\begin{array}{c}30.5(19.7- \\
43.9)\end{array}$ & $\begin{array}{c}31.8(22.3- \\
40.6)\end{array}$ & $\begin{array}{c}43.3(29.5- \\
55.4)\end{array}$ \\
\hline & $\begin{array}{l}\text { Min - } \\
\text { Max }\end{array}$ & $6.6-113.0$ & $8.2-162.2$ & $11.9-66.0$ \\
\hline \multirow{2}{*}{$\begin{array}{l}\text { Vitamin D } \\
\mathbf{N}=\mathbf{3 0}-\mathbf{1 0 0} \\
\mathbf{n g} / \mathbf{m l}\end{array}$} & $\begin{array}{l}\text { Median } \\
\text { (IQR) }\end{array}$ & $\begin{array}{c}14.0(10.9- \\
\mathbf{1 7 . 5})\end{array}$ & $\begin{array}{c}18.1(13.0- \\
\mathbf{2 5 . 2})\end{array}$ & $\begin{array}{l}22.5(12.0- \\
\mathbf{2 9 . 5})\end{array}$ \\
\hline & $\begin{array}{l}\text { Min - } \\
\text { Max }\end{array}$ & $6.1-23.1$ & $6.0-58.9$ & $6.6-34.9$ \\
\hline \multirow{2}{*}{$\begin{array}{l}\text { Alkaline } \\
\text { Phosphatase } \\
=<\mathbf{2 7 0} \text { U/L }\end{array}$} & $\begin{array}{l}\text { Median } \\
\text { (IQR) }\end{array}$ & $\begin{array}{c}130.0(100.5 \\
-145.5)\end{array}$ & $\begin{array}{c}131.0(104.0 \\
-162.0)\end{array}$ & $\begin{array}{c}132.5(112.0 \\
-171.0)\end{array}$ \\
\hline & $\begin{array}{l}\text { Min - } \\
\text { Max }\end{array}$ & $81.0-174.0$ & $76.0-373.0$ & $96.0-235.0$ \\
\hline \multirow{2}{*}{$\begin{array}{l}\text { T Calcium } \\
\mathrm{N}= \\
9.2-11.0 \\
\mathbf{m g} / \mathbf{d l}\end{array}$} & $\begin{array}{l}\text { Median } \\
(\mathrm{IQR})\end{array}$ & $9.1(8.8-9.7)$ & $\begin{array}{c}9.3(8.9- \\
10.2)\end{array}$ & $\begin{array}{c}9.2(8.6- \\
9.5)\end{array}$ \\
\hline & $\begin{array}{l}\text { Min - } \\
\text { Max }\end{array}$ & $7.5-9.9$ & $7.2-12.0$ & $7.5-11.6$ \\
\hline \multirow{2}{*}{$\begin{array}{l}\text { Phosphorus } \\
\text { 2.7-4.5 } \\
\text { mg/dl }\end{array}$} & $\begin{array}{l}\text { Median } \\
\text { (IQR) }\end{array}$ & $5.0(4.2-5.9)$ & $\begin{array}{c}4.8(4.1- \\
5.6)\end{array}$ & $\begin{array}{c}4.4(3.8- \\
4.9)\end{array}$ \\
\hline & $\begin{array}{l}\text { Min - } \\
\text { Max }\end{array}$ & $2.6-6.6$ & $2.9-6.8$ & $3.1-5.7$ \\
\hline \multirow{2}{*}{$\begin{array}{l}\mathrm{Ca} * \mathrm{P} \\
=<\mathbf{7 0} \mathbf{~ m g}^{2} \\
/ \mathbf{d} \mathbf{L}^{2}\end{array}$} & $\begin{array}{l}\text { Median } \\
\text { (IQR) }\end{array}$ & $\begin{array}{c}43.7(35.7- \\
56.0)\end{array}$ & $\begin{array}{c}46.8(38.2- \\
53.0)\end{array}$ & $\begin{array}{c}39.2(33.9- \\
49.8)\end{array}$ \\
\hline & $\begin{array}{l}\text { Min - } \\
\operatorname{Max}\end{array}$ & $22.9-63.4$ & $23.8-64.7$ & $23.3-57.2$ \\
\hline
\end{tabular}

$* I Q R=$ Inter-quartile range $\left(2^{\text {nd }}\right.$ and $3^{\text {rd }}$ quartiles including median value $)(>=25 \%$ to $=<75 \%$ of results) 
Does Fresh Air make the Difference; a Comparative Study in Vitamin D Status among College Adolescent Females from Giza and Red Sea Governorates

Dina $I S^{l}$, El-Sayed $M M^{2}$, and Salem $\mathrm{AH}^{3}$

Table (5): Percent Frequency Distribution of Participant Females per Season based on Cut-offs of VD*, PTH*, and Calcium Simultaneously (Metabolic State)

\begin{tabular}{|c|c|c|c|c|c|c|c|c|c|c|}
\hline \multirow[t]{3}{*}{ Season } & \multicolumn{8}{|c|}{$\begin{array}{c}\text { Cut-offs of VD, PTH, and Calcium Simultaneously } \\
\text { State) }\end{array}$} & \multirow{2}{*}{\multicolumn{2}{|c|}{ Total }} \\
\hline & \multicolumn{2}{|c|}{$\begin{array}{c}\text { VDD } \\
\text { (PTH high, } \\
\text { and VD and } \\
\text { Ca are low) }\end{array}$} & \multicolumn{2}{|c|}{$\begin{array}{c}\text { VDI } \\
\text { (PTH high, } \\
\text { regardless of } \\
\text { VD level) }\end{array}$} & \multicolumn{2}{|c|}{$\begin{array}{c}\text { Hypo Ca } \\
\text { (low Ca with } \\
\text { normal PTH } \\
\text { and VD) }\end{array}$} & \multicolumn{2}{|c|}{$\begin{array}{c}\text { VDN } \\
\text { (PTH, VD, } \\
\text { and Ca are } \\
\text { normal) }\end{array}$} & & \\
\hline & No & $\begin{array}{c}\text { row } \\
\%\end{array}$ & No & $\begin{array}{c}\text { row } \\
\%\end{array}$ & No & $\begin{array}{c}\text { row } \\
\%\end{array}$ & No & $\begin{array}{l}\text { row } \\
\%\end{array}$ & No & $\begin{array}{c}\text { Col. } \\
\%\end{array}$ \\
\hline \multicolumn{11}{|l|}{ Red sea } \\
\hline Winter & 3 & 18.0 & 1 & 6.0 & 2 & 12.0 & 11 & 64.0 & 17 & 25.0 \\
\hline Autumn & 3 & 13.0 & 1 & 4.0 & 4 & 17.0 & 15 & 65.0 & 23 & 33.0 \\
\hline \multirow[t]{2}{*}{ Spring } & 5 & $\mathbf{1 7 . 0}$ & 2 & 7.0 & 12 & 41.0 & $\mathbf{1 0}$ & 35.0 & 29 & 42.0 \\
\hline & \multicolumn{10}{|c|}{ Likelihood Ratio $=8.13 \quad \mathrm{df}=6$} \\
\hline \multicolumn{11}{|l|}{ Giza } \\
\hline Winter & 4 & 24.0 & --- & $\mathbf{0 . 0}$ & 6 & 35.0 & 7 & 41.0 & 17 & 21.0 \\
\hline Autumn & 5 & 14.0 & 2 & 6.0 & 4 & 11.0 & 24 & 69.0 & 35 & 42.0 \\
\hline \multirow[t]{2}{*}{ Spring } & 13 & 43.0 & 4 & 13.0 & 4 & 13.0 & 9 & 31.0 & 30 & 37.0 \\
\hline & \multicolumn{10}{|c|}{ Likelihood Ratio $=17.673 \quad \mathrm{df}=6$} \\
\hline \multicolumn{11}{|l|}{ Total } \\
\hline Winter & 7 & 21.0 & 1 & 3.0 & 8 & 24.0 & 18 & 53.0 & 34 & 23.0 \\
\hline Autumn & 8 & 14.0 & 3 & 5.0 & 8 & 14.0 & 39 & 67.0 & 58 & 38.0 \\
\hline \multirow[t]{2}{*}{ Spring } & 18 & 31.0 & 6 & 10.0 & 16 & 27.0 & 19 & 32.0 & 59 & 59.0 \\
\hline & \multicolumn{10}{|c|}{ Likelihood Ratio $=15.99 \quad 1 \mathrm{df}=6$} \\
\hline \multicolumn{11}{|l|}{ Both } \\
\hline Red Sea & 11 & 16.0 & 4 & 6.0 & 18 & 26.0 & 36 & 52.0 & 69 & 46.0 \\
\hline Giza & 22 & 27.0 & 6 & 7.0 & 14 & 17.0 & 40 & 49.0 & 82 & 54.0 \\
\hline \multirow[t]{2}{*}{ Total } & 33 & 22.0 & 10 & $\mathbf{7 . 0}$ & 32 & 21.0 & 76 & $\mathbf{5 0 . 0}$ & 151 & 100.0 \\
\hline & \multicolumn{10}{|c|}{ Likelihood Ratio =3.73 } \\
\hline
\end{tabular}


Does Fresh Air make the Difference; a Comparative Study in Vitamin D Status among College Adolescent Females from Giza and Red Sea Governorates

Dina $I S^{1}$, El-Sayed $M M^{2}$, and Salem $\mathrm{AH}^{3}$

Table (6): Average daily Intake of Main Macro- and Micro-nutrients presented as median (IQR*) among participant females per Governorate

\begin{tabular}{|c|c|c|c|c|c|}
\hline \multicolumn{2}{|c|}{ Nutrients $(\mathrm{RDA})^{* *}$} & Red sea & Giza & $\mathrm{MW}^{* * *}$ & $\mathrm{P}$ \\
\hline \multirow{2}{*}{$\begin{array}{l}\text { Calories } \\
(\mathbf{2 2 0 0} \\
\text { Kcal/day) }\end{array}$} & Median (IQ) & $\begin{array}{c}1713.0(1411.0- \\
2031.0)\end{array}$ & $\begin{array}{c}1776.7(1329.0- \\
2204.3)\end{array}$ & \multirow[t]{2}{*}{-0.067} & \multirow[t]{2}{*}{0.946} \\
\hline & Min - Max & $683.0-4188.0$ & $57.0-3202.0$ & & \\
\hline \multirow{2}{*}{$\begin{array}{l}\text { Protein }^{* * * * *} \\
(42.1-50.8 \\
\text { g/day) }\end{array}$} & Median (IQ) & $66.0(52.0-83.0)$ & $60.8(42.0-84.3)$ & \multirow[t]{2}{*}{-0.822} & \multirow[t]{2}{*}{0.411} \\
\hline & Min - Max & $13.0-175.9$ & $2.0-120.0$ & & \\
\hline \multirow{2}{*}{$\begin{array}{l}\text { Calcium } \\
(\mathbf{1 2 0 0} \\
\mathbf{m g / d a y )}\end{array}$} & Median (IQ) & $\begin{array}{c}571.0(386.3- \\
750.7)\end{array}$ & $\begin{array}{c}442.0(332.0- \\
648.0)\end{array}$ & \multirow[t]{2}{*}{-1.700} & \multirow[t]{2}{*}{$\underline{0.089}$} \\
\hline & Min - Max & $128.0-1274.6$ & $11.0-1236.3$ & & \\
\hline \multirow{2}{*}{$\begin{array}{l}\text { Phosphorus } \\
(\mathbf{1 2 5 0} \\
\text { mg/day) }\end{array}$} & Median (IQ) & $\begin{array}{c}925.6(810.0- \\
1072.0)\end{array}$ & $\begin{array}{c}770.0(579.0- \\
1005.0)\end{array}$ & \multirow[t]{2}{*}{-2.183} & \multirow[t]{2}{*}{0.029} \\
\hline & Min - Max & $168.0-2293.1$ & $17.0-1941.0$ & & \\
\hline \multirow{2}{*}{$\begin{array}{l}\mathrm{Ca} / \mathrm{iP} \\
\text { ratio } \\
(2: 1)\end{array}$} & Median (IQ) & $0.6(0.5-0.7)$ & $0.6(0.4-0.7)$ & \multirow[t]{2}{*}{-0.163} & \multirow[t]{2}{*}{0.871} \\
\hline & Min - Max & $0.3-1.9$ & $0.2-1.6$ & & \\
\hline \multirow{2}{*}{$\begin{array}{l}\text { Iron } \\
(29-31 \\
\text { mg/day) }\end{array}$} & Median (IQ) & $11.0(8.5-16.0)$ & $12.0(8.5-17.0)$ & \multirow[t]{2}{*}{-0.723} & \multirow[t]{2}{*}{0.470} \\
\hline & Min - Max & $2.0-32.6$ & $1.0-35.0$ & & \\
\hline \multirow{2}{*}{$\begin{array}{l}\text { Zinc } \\
(8 \mathrm{mg} / \text { day })\end{array}$} & Median (IQ) & $9.0(7.0-11.0)$ & $9.0(6.4-12.0)$ & \multirow[t]{2}{*}{-0.352} & \multirow[t]{2}{*}{0.725} \\
\hline & Min - Max & $1.0-30.6$ & $1.0-19.0$ & & \\
\hline
\end{tabular}

\footnotetext{
* IQR = Inter-quartile range (2nd and 3rd quartiles including median value) ( $>=25 \%$ to $=<75 \%$ of results)

**RDA= recommended daily allowance based on WHO/FAO (2004)

**** MW=Mann-Whitney Test

****FAO/WHO/UNU (2007)
} 
Does Fresh Air make the Difference; a Comparative Study in Vitamin D Status among College Adolescent Females from Giza and Red Sea Governorates

Dina $I S^{I}$, El-Sayed $M M^{2}$, and Salem $\mathrm{AH}^{3}$

Table (7): Non-parametric Correlations between Vitamin D State and some Environmental Risk Factors

\begin{tabular}{|c|c|c|c|c|c|c|c|c|c|}
\hline \multirow[t]{3}{*}{ Risk factors } & \multicolumn{9}{|c|}{ Vitamin D Metabolic status* } \\
\hline & \multicolumn{3}{|c|}{ Giza } & \multicolumn{3}{|c|}{ Red Sea } & \multicolumn{3}{|c|}{ Both } \\
\hline & $\mathbf{r}$ & $\mathbf{p}$ & No & $\mathbf{r}$ & $\mathbf{p}$ & No & $\mathbf{r}$ & $\mathbf{p}$ & No \\
\hline $\begin{array}{l}\text { Autumn } \\
\text { Spring }\end{array}$ & $\begin{array}{l}+0.33 \\
-0.34\end{array}$ & $\begin{array}{l}0.002 \\
0.000\end{array}$ & 82 & -0.243 & $\begin{array}{l}\text { NS } \\
0.044\end{array}$ & 69 & $\begin{array}{c}+0.251 \\
-0.288\end{array}$ & $\begin{array}{l}0.002 \\
0.000\end{array}$ & 151 \\
\hline $\begin{array}{l}\mathrm{HH} \mathrm{No}^{* *} \\
\text { Crowdedness } \\
\text { index }\end{array}$ & 0.134 & 0.10 & 82 & $\begin{array}{r}+0.276 \\
+0.195\end{array}$ & $\begin{array}{l}0.022 \\
0.108\end{array}$ & $\begin{array}{l}69 \\
69\end{array}$ & +0.134 & 0.10 & 151 \\
\hline Income & 0.129 & 0.11 & 82 & & NS & 69 & +0.192 & 0.113 & 151 \\
\hline Sun screen & & NS & 82 & +.276 & .026 & 69 & +0.162 & 0.057 & 151 \\
\hline $\begin{array}{l}\text { Sun exp. } \\
\text { noon }\end{array}$ & & NS & 70 & -0.310 & 0.014 & 62 & -0.176 & 0.044 & 132 \\
\hline $\begin{array}{l}\text { Closed } \\
\text { window }\end{array}$ & & NS & 70 & & NS & 62 & & NS & 132 \\
\hline waist & +0.248 & 0.05 & 82 & & NS & 69 & & NS & 151 \\
\hline $\mathrm{WC}$ to $\mathrm{Ht}$ & +0.218 & 0.025 & 82 & & NS & 69 & & NS & 151 \\
\hline
\end{tabular}

* Vitamin D Metabolic Status is the re-classification of laboratory results based on the normal physiological PTH-VD axis using cut-offs of vitamin D, calcium, and phosphorus in relation to cut-offs of PTH

**HH No= household number 
Does Fresh Air make the Difference; a Comparative Study in Vitamin D Status among College Adolescent Females from Giza and Red Sea Governorates

Dina IS ${ }^{1}$, El-Sayed $M M^{2}$, and Salem $\mathrm{AH}^{3}$

Table (8): Non-parametric Correlations between Vitamin D State and some Dietary Influential Factors

\begin{tabular}{|c|c|c|c|c|c|c|c|c|c|}
\hline \multirow[t]{3}{*}{ Risk factors } & \multicolumn{9}{|c|}{ Vitamin D Metabolic status* } \\
\hline & \multicolumn{3}{|c|}{ Giza } & \multicolumn{3}{|c|}{ Red Sea } & \multicolumn{3}{|c|}{ All } \\
\hline & $\mathbf{r}$ & $\mathbf{p}$ & No & $\mathbf{r}$ & $\mathbf{p}$ & No & $\mathbf{r}$ & $\mathbf{p}$ & No \\
\hline $\begin{array}{l}\mathrm{Ca} \% \mathrm{RDA} \\
\mathrm{Ca} / 1000 \\
\mathrm{kcal} \\
\mathrm{Ca} \mathrm{mg} / \mathrm{d}\end{array}$ & - 0.176 & $\begin{array}{c}\text { NS } \\
0.108 \\
\text { NS }\end{array}$ & 56 & $\begin{array}{r}-0.353 \\
-0.325 \\
-0.353\end{array}$ & $\begin{array}{c}0.06 \\
0.085 \\
0.06\end{array}$ & 29 & - & $\begin{array}{c}\text { NS } \\
0.108 \\
\text { NS }\end{array}$ & 85 \\
\hline $\begin{array}{l}\mathrm{P} \text { in diet } \\
\mathrm{mg} / \mathrm{d} \\
\% \text { RDA }\end{array}$ & & $\begin{array}{l}\text { NS } \\
\text { NS }\end{array}$ & 56 & $\begin{array}{l}-0.329 \\
-0.329\end{array}$ & $\begin{array}{l}0.08 \\
0.08\end{array}$ & 29 & & $\begin{array}{l}\text { NS } \\
\text { NS }\end{array}$ & 85 \\
\hline $\begin{array}{l}\text { Iron in diet } \\
\mathrm{mg} / \mathrm{d} \\
\% \mathrm{RDA}\end{array}$ & $\begin{array}{l}+0.337 \\
+0.296\end{array}$ & $\begin{array}{l}0.011 \\
0.027\end{array}$ & 56 & & $\begin{array}{l}\text { NS } \\
\text { NS }\end{array}$ & 29 & +0.184 & $\begin{array}{c}0.099 \\
\text { NS }\end{array}$ & 85 \\
\hline $\begin{array}{l}\text { Zinc in diet } \\
\mathrm{mg} / \mathrm{d} \\
\% \text { RDA }\end{array}$ & $\begin{array}{l}+0.318 \\
+0.287\end{array}$ & $\begin{array}{c}.017 \\
.03\end{array}$ & 56 & $\begin{array}{l}-0.346 \\
-0.313\end{array}$ & $\begin{array}{l}0.066 \\
0.099\end{array}$ & 29 & & $\begin{array}{l}\text { NS } \\
\text { NS }\end{array}$ & 85 \\
\hline $\begin{array}{l}\text { Cross } \\
\text { vegetables }\end{array}$ & +0.25 & 0.035 & 71 & & NS & 14 & +0.213 & 0.016 & 85 \\
\hline Fish & & NS & & 0.309 & .02 & 56 & & NS & 85 \\
\hline Trans-fat & -0.234 & 0.049 & 71 & & NS & 14 & -0.171 & 0.055 & 85 \\
\hline $\mathrm{Na}$ in diet & & NS & 56 & -0.389 & 0.037 & 29 & & $\mathbf{N S}$ & 85 \\
\hline Meal no. & +0.203 & 0.09 & 71 & & $\mathbf{N S}$ & 14 & & NS & 85 \\
\hline $\begin{array}{l}\text { Protein } \\
\text { g/d } \\
\text { Protein } \\
\text { Energy\% }\end{array}$ & $\begin{array}{l}+0.324 \\
+0.255\end{array}$ & $\begin{array}{l}0.016 \\
0.099\end{array}$ & 71 & & $\begin{array}{l}\text { NS } \\
\text { NS }\end{array}$ & 14 & & NS & 85 \\
\hline $\begin{array}{l}\text { Full cream } \\
\text { milk }\end{array}$ & +0.193 & 0.107 & 71 & & NS & 14 & & NS & 85 \\
\hline $\begin{array}{l}\text { Natural } \\
\text { Cheese }\end{array}$ & & NS & & -0.258 & 0.054 & 56 & & NS & \\
\hline
\end{tabular}




\section{هل يحدث الهواء النقي الفارق؟ دراسة مقارنة علي حالة

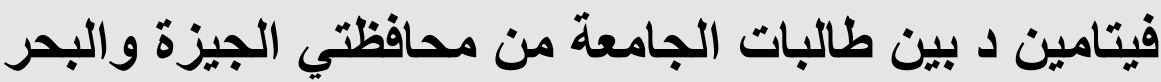 الاحمر من}

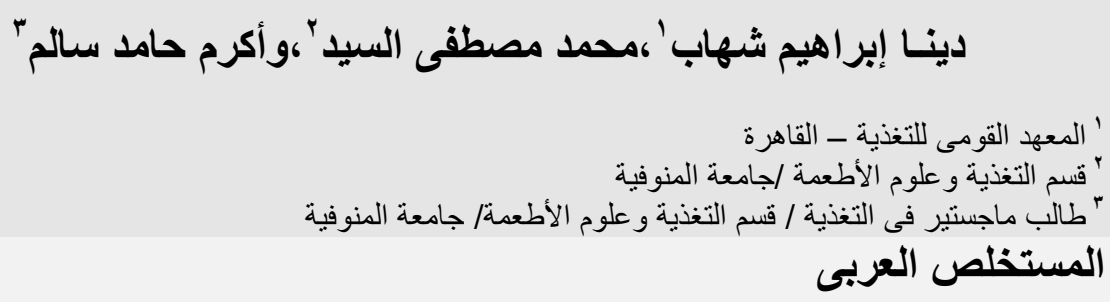

تلوث الهواء هو أحد العناصر الرئيسية التي تؤثر على النسبة المئوية للأشعة فوق البنفسجية

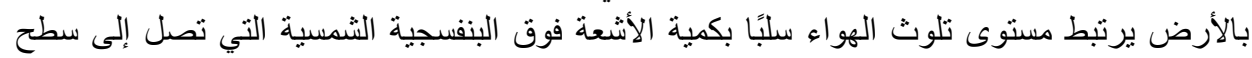

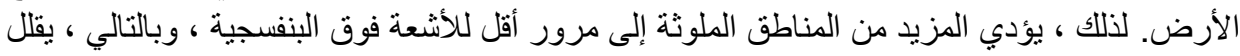

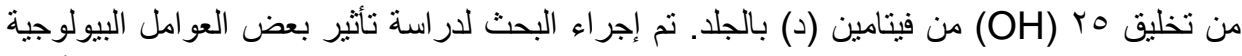

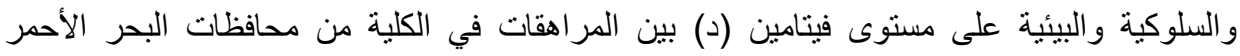

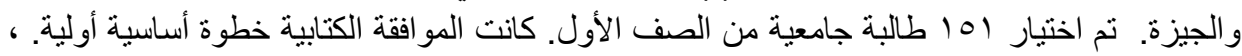

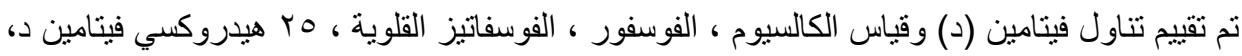

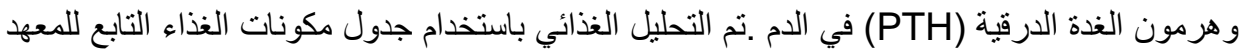

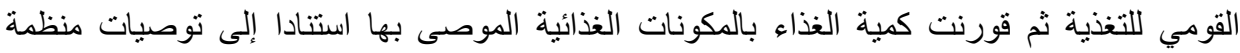

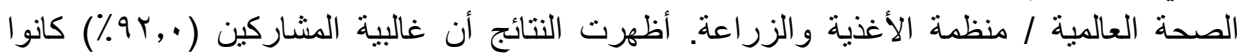

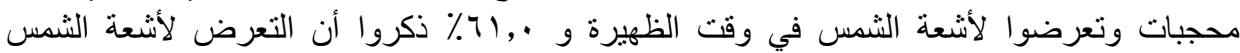

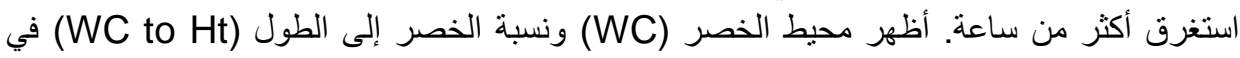

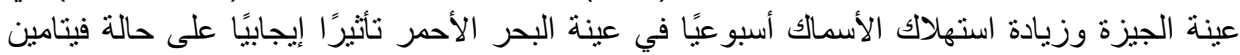

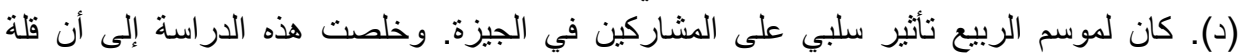

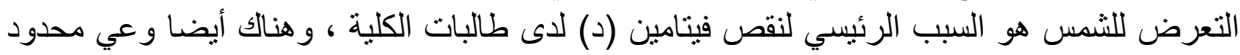

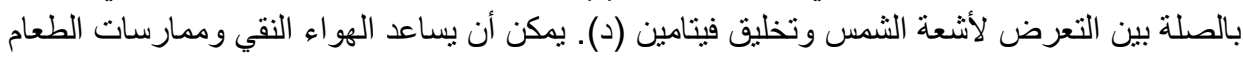

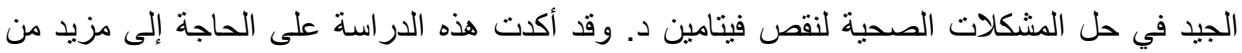

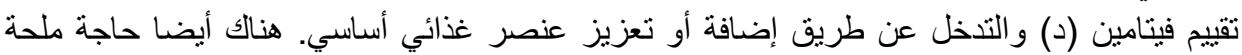

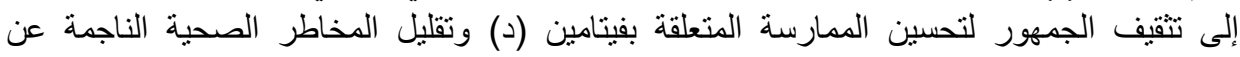
التعرض غير السليم لأشعة فوق البنفسجية.

الكلمات المفتاحية: أشعة الشمس ، مصادر فيتامين د الغذائية ، طالبات الجامعيات 